Article

\title{
Modern Circular Economy: Corporate Strategy, Supply Chain, and Industrial Symbiosis
}

\author{
Cristina Maranesi ${ }^{1, *, \dagger}$ and Pietro De Giovanni ${ }^{1,2, *,+}$ \\ 1 Department of Business and Management, Luiss University, Viale Romania, 00197 Rome, Italy \\ 2 X.ite Research Center on Economic Behavior and Technology, Viale Romania, 00197 Rome, Italy \\ * Correspondence: cristina.maranesi@studenti.luiss.it (C.M.); pdegiovanni@luiss.it (P.D.G.) \\ $\dagger$ These authors contributed equally to the work.
}

Received: 8 October 2020; Accepted: 9 November 2020; Published: 11 November 2020

\begin{abstract}
This paper analyses the firms' chances to consider circular economy as a part of the corporate strategy. The analysis of four Italian firms engaged in circular economy programs allows us to detect its connections with the corporate strategy, the real activities involved, the supply chain network ensuring circularity, the industrial symbiosis, as well as the links with performance. Our findings highlight that circular economy is a true business lever when the corporate strategy complements and supports its development. This allows firms to achieve high level targets that go beyond the traditional targets of social, environmental, and economic performance, and include circular supply chain, eco-innovations, and industrial symbiosis.
\end{abstract}

Keywords: circular economy; corporate strategies; performance; eco-innovation; industrial symbiosis

\section{Introduction}

Our planet is experiencing accelerated climate change and environmental degradation [1]. The material consumption is expected to double over the next forty years along with an annual waste generation increase of $70 \%$ by 2050 [2]. Furthermore, the public pressure on environmental issues, strict regulations, and the high levels of competition push firms to include environmental concerns, actions, and targets into their strategic planning and progressively adopt circular business models [3]. Firms adopting a circular economy (CE) can significantly contribute to achieve climate neutrality by 2050 and decouple economic growth from resource use. In fact, CE is indeed a key approach for the transition to a more sustainable economic paradigm that enables the minimization of resource usage, waste, emissions, and energy leakages as well as the closing of material and energy loops [4].

Embracing the CE systems and strategies requires changes at macro and micro levels. At the macro level, the European Union has sponsored the Circular Economy Action Plan in 2015. This plan specifies the opportunity for countries to invest in the area of $\mathrm{CE}$ and be evaluated by a specific monitoring platform called the Circular Economy Monitoring Framework. Italy has undertaken the EU's plan by initializing the National Strategy for Sustainable Development (approved in 2017), which consists of a national CE strategy and action plan. This plan, used at a micro level, allows firms to have a great opportunity for implementing CE systems and being supported by the Italian government's actions and funds.

Sustainable economic systems and circular business models are attracting the attention of both researchers and practitioners. Companies are progressively integrating sustainability into their corporate goals and are actively engaging with their stakeholders on corporate social responsibility (CSR) targets [5]. In this context, as highlighted in Ref. [6], CE represents a real opportunity to integrate sustainability into the company's vision and reconcile CSR goals. This paper seeks to find how CE, besides sustainability, can also exert a real business opportunity for companies and a tool to integrate 
within the Supply Chain (SC) network. In fact, the CE paradigm needs the firms' boundaries be extended to supply chains partners that have the same orientation towards circularity. Among the extant literature, Ref. [7] have conceptualized a unifying definition of circular supply chain (CSC) management. The latter consists of a set of green strategies and CE practices enabling the continuous circulation of value and resources, collaborations with both upstream/downstream partners as well as industrial partners [8]. CSCs are sustainable enablers that currently require more investigation [9]. In fact, firms still need to identify the path for developing CSCs [7]. Accordingly, this research aims at investigating the current CE practices available to successfully implement CSCs.

From the methodological side, this study develops a multiple case study analysis of four Italian companies working in different sectors. Our findings show that $\mathrm{CE}$ is a business opportunity for companies. However, its success requires both the shareholders' and top management's engagement to drive technology and innovation projects as well as industrial partnerships with the intent to implement integrated CSCs and effectively push for both cultural and organizational changes. Therefore, companies engaging in $\mathrm{CE}$ enjoy growth and competitiveness along with social, economic, and environmental benefits

This study is organized as follows. The next section provides a literature review on circular economy and circular supply chains, CSC implementation aspects, and CE main benefits. Then, the methodology section provides details on the research approach used to collect data. The findings and discussion sections present key results and provide answers to the questions emerging from the literature. The study ends by providing conclusions and limitations.

\section{Literature Review}

\subsection{Introduction to Circular Economy and Its Implementation}

Environmental impacts are jeopardizing the Earth's life-support systems [10,11] and the conventional business modus operandi "take-make-dispose" is no longer sufficient [12]. In this context, the concept of $\mathrm{CE}$ has acquired growing attention from both researchers and practitioners and was motivated by ecological degradation, changing socio-economic needs, and dynamic regulatory landscapes. We used the definition by Ref. [13] according to who a CE is "an economic system that is based on business models that replace the 'end-of-life' concept with reducing, alternatively reusing, recycling and recovering materials in production/distribution and consumption processes; thus, it applies at the micro level (products, companies, consumers), meso level (eco-industrial parks), and macro level (city, region, nation and beyond), with the aim to accomplish sustainable development by creating environmental quality, economic prosperity, and social equity, and benefits for both the current and the future generations". The implementation of CE consists of reducing materials' usage and substituting them with easily upgradable and long-lasting products or products made with renewable resources and/or through resource recovery processes (recycling, upcycling, downcycling). When adopting CE, companies need to involve and integrate all the business functions over their network through the implementation of circular supply chains (CSCs). In this context, companies should also consider the EU Waste Framework Directive and its hierarchy of waste, which allows us to identify the main practices that companies can implement:

- Prolong and share: prolong product/material lifespan through proper design and maintenance; share products to provide access to the related services as well as to other customers;

- Reuse/redistribute: use multiple times or also redistribute to new users;

- Refurbishing/remanufacturing: implement an "aesthetic process" to repair generally without disassembling; replace bad components to bring the product at a "like new state";

- Recycle: reduce to basic materials and reuse at least a part of them to generate new products;

- Cascades: implement the biological cycle until the material returns as a nutrient to the soil. 
Considering that the knowledge and the tools for bringing CE into practice still need to be fully developed and deeply analyzed [8], we seek to answer the following research question:

RQ1. How is circular economy really implemented by companies?

\subsection{Circular Economy Role within Corporate Strategies}

Nowadays, firms need new corporate strategies and models to safeguard profitability and competitiveness as well as the heritage of natural resources. Governments and international organizations promote initiatives to accelerate the shift to new policies [14]. In view of the external pressure, firms have to achieve the triple bottom line, pursuing economic performance, improving the environmental impacts and contributing to society [15]. These targets can be achieved by progressively integrating sustainability into the corporate goals [5]. An active engagement on CSR generates favorable stakeholder attitudes in supporting green initiatives. As highlighted by Ref. [6], CE represents an enormous opportunity to integrate sustainability into the company's vision and reconcile economic, environmental, and social goals. In Ref. [16], the authors show the benefits that companies obtain when they move from a non-integrated to an integrated CE program, which requires trust, commitments, and support from the top management. The top management attention and leadership are fundamental to drive CE strategies towards long-term growth and competitiveness [17].

Indeed, firms can respond to sustainability challenges in a different way, either proactively or defensively, according to the business models and priorities. Some firms promote green and circular initiatives to pursue "ethical leadership" and generate positive impacts on the corporate's image [18]; other firms mainly target cost reduction through a better usage of raw materials while other firms focus on energy consumption and savings [19]. Nonetheless, the adoption of CE principles requires a fundamental shift in the way of conducting business, focusing towards designing out waste and pollution, keeping products and materials in use, and regenerating natural systems. Following these principles and practices, CE implementation articulates on the following main pillars and related business models [20]:

- Circular inputs: use of bio-based or potentially completely recyclable material; use of renewable energy to reduce the environmental footprint;

- Sharing platforms: collaborative models between users and owners for the use/access of goods and services to increase the usage rates;

- Product as a service: leaving the product ownership to the producer in order to increase resource productivity;

- Resource recovery: recover usable resources/energy from waste or products;

- Product use extension: prolongation of product use and life through modular design, repair, upgrading, and resale.

Considering that sustainable development and, in particular, the CE adoption and implementation are long-term goals that require the intervention and guidance of top management, we seek to address the following research question:

RQ2. How does circular economy relate to corporate strategy?

\subsection{Circular Supply Chains}

SCs allow coordination with partners that also considers environmental practices $[8,21]$. This coordination becomes a key element to achieve a successful CE since SCs allow firms to align also in terms of environmental targets [22] and sponsors the development of Circular Supply Chain (CSC) Management. CSC is defined as "the integration of circular thinking into the management of the supply chains and its surrounding industrial and natural ecosystems. It systematically restores materials toward a zero-waste vision through innovation from product/service design to end-of-life and waste management, involving all stakeholders" [4,7]. 
CSCs imply new design approaches that incorporate the concept of lifetime extension, reuse/ recycling processes as well as take back, refurbish, and resell tasks [4]. CSCs also include green manufacturing and cleaner production, focused on high levels of eco-efficiency that is reached through environmental protection and resource conservation [23]. In particular, Ref. [24] have conceptualized the transition from the linear supply chain to the circular supply chain. Considering the backward flows, the reverse logistics process is a key driver to make it possible [25]. Reverse processes can imply closed-loop systems, where materials or products are returned back to the original manufacturers [26], or open-loop systems when the end-of-life/use goods are recovered by other parties [27].

CSCs enable processes that improve the lifespan of products, the material regeneration [28], and the value recovery from waste through the collaboration with organizations in other industrial sectors [29]. In this latter case, collaborative business approaches that increase the resource efficiency are known with the term industrial symbiosis (IS). "IS engages multiple organizations in a network to foster eco-innovation ... creating and sharing knowledge ... for novel sourcing of required inputs, value-added destinations for non-product outputs, and improved business and technical processes" [30]. The resulting mutual benefits in terms of cost reduction, increased revenues, and competitive advantages transform synergies into attractive business opportunities.

The implementation of CSCs can be fostered through technologies that enable higher levels of efficiency and transparency. Blockchain is a typical technology that can help firms implement the CSC by granting information transparency, reliability, and traceability [31,32]. By using an optimization algorithm to solve a problem with a complex supply chain with four tiers, Ref. [33] shows that the use of blockchain technology in a circular economy can help companies and SCs to record emissions over the SC and develop a true green SC. Some new technologies enable the production of specific materials_-"material technology" - designed to fit with biological and technical-circular processes and are thus biodegradable or easily recyclable/dismantlable. Three-dimensional printing and augmented reality are instead more suitable for product design and manufacturing processes [34]. In Ref. [35], the authors demonstrated that the artificial intelligence system developed by IBM and named Supply Chain Insights allows firms to reduce the uncertainty linked to environmental collaboration and global sourcing management. In Ref. [7], the authors introduced a survey on CE and identified the main keys to optimize the CE network. They suggested taking a closer look to all Industry 4.0 technologies since they offer potential benefits to improve $C E$ performance. An effective $C E$ requires synergies among all actors and across industries and sectors [36].

In this complex system, firms need to develop CSCs to monitor and track performance [37]. Among the institutional initiatives developed for CE measurement, the EU "Circular Economy Monitoring Framework" (EMF) is an important tool that consists of four dimensions: production and consumption, waste management, secondary raw materials, competitiveness and innovation. These dimensions seek to track CE systems [38]. Furthermore, the EMF has elaborated an index to specifically support the entrepreneurial system, the Material Circularity Indicator. This latter is composed by 10 sub-indicators: the first four relate strictly to the $\mathrm{CE}$ and include the percentage of virgin raw material, the amount of non-recoverable waste, the percentage of material with linear flow, and the product usage intensity. The remaining six sub-indicators refer instead to the additional risk and impact factors [37].

In line with the aforementioned indicators, the Life Cycle Assessment (LCA) is a tool that quantifies the sustainability impacts of various products, processes, and industrial systems for both research and practical needs $[1,39]$. Based on life cycle thinking, the LCA defines the consumption of resources (materials, water, energy) and the impacts on the surrounding environment at all the stages of the product/service life cycle [40]. The steps included are the definition of goals and scope, the definition of the life cycle inventory (input-output), the assessment of the environmental impacts and the final interpretation of the results [41]. The evolution in the use of the LCA approach was studied in Ref. [42], from a mere energy analysis to a more comprehensive assessment including measurements of resource requirements, emission loadings, and the generated waste. The comprehensive scope of the LCA makes it useful not only to provide a complete evaluation but also to prevent a shift among phases, geographic 
regions, or environmental issues [43]. In the end, in view of the role of CSCs as enablers of the business response to the principles of the $\mathrm{CE}$ and the needs for a more comprehensive understanding, we sought to answer the following research question:

RQ3. What are the sustainability programs adopted for implementing circular supply chains?

\subsection{The Relational Dimension of the Circular Economy}

The CE thinking implies adjustments/changes at all the stages of the supply chain and requires a shared CE-oriented vision among all the stakeholders involved [44]. The involvement of multiple stakeholders and the development of deep working relations can, indeed, be fundamental to pursue mutually supporting progress and a higher level of competitiveness [45].

The literature has documented the importance of the relational structure within SCs; how collaboration and interactions between SC members can lead to superior operational and environmental performances [24,46]. Around 70\% of the products cost refers to raw materials [47]. In particular, the stakeholders' involvement can support a more effective sustainability approach and the transition toward the CE [26]. Consortia are fundamental in CSCs as they enable the valorization of waste as new resources, contribute to a growing recovery system and material usage. Furthermore, Ref. [48] have empirically analyzed supplier participation in green initiatives and have shown how suppliers can foster the greening transformation and ensure high efficiency and responsiveness [49]. Furthermore, critical SC relationships can lead to resources and knowledge sharing, better risk management and higher organizational sustainability [50,51].

Considering these data, supplier and partner selection is becoming a crucial routine for implementing successful CSCs. The modern selection criteria go beyond standard features like price, quality, and lead time [52] and include green practices, programs, and attitudes [53]. Companies look for suppliers that are concerned about environmental issues and are able to provide technically restorative and regenerative materials [26]. The new criteria for sustainable supplier selection can include environmental certifications, pollution control indicators, the level of substitution of discarded products with respect to original virgin materials, and processes implemented to be green (quality checks, disassembling, etc.) [34]. The sustainability efforts of manufacturers, suppliers, and retailers should be aligned to meet the expectations of the targeted market segments; much of the SC success depends on the ability to predict and meet customers' expectations [54]. In particular, customers have an active role in the recovery of products and the recycling of waste materials; companies should encourage green purchasing behaviors [55], and support higher levels of awareness and education on sustainability issues [7].

Within the relational dimension, industrial symbiosis (IS) is progressively contributing to the development of CE. The role of IS as a modern device to foster eco-innovation and sustainability was recognized by the authors in Ref. 30]. Creating and sharing knowledge among companies provides mutually profitable transactions for the novel sourcing of inputs, valuable destinations for non-product outputs, and improved processes [30]. More recently, Ref. [45] also showed how companies can find an innovative and optimized source of inputs through IS. IS is a fertile ground for eco-innovation leading to environmental benefits, competitiveness, and economic growth [56,57]. In this context, the concepts of sustainable oriented innovation (SOI) and of collaborative circular innovation (COI) are emerging. COI, in particular, is emphasizing the role of collaborative approaches for the development of the radical innovations required by $\mathrm{CE}$ and fosters additional related benefits such as access to resources, new markets, and enhanced skills, as well as eventually shared risks [58]. In order to better identify the main stakeholders and understand how they interact in the CE context, we investigated the following research question:

RQ4. Which stakeholders and IS do contribute the most to the implemenation of circular supply chain? 


\subsection{Circular Economy Main Benefits and Opportunities}

The implementation of $\mathrm{CE}$ is motivated by the potential benefits related to environmental, economic, and social performance, that is, the Triple Bottom Line. The pressure from climate change and global warming are accelerating firms' willingness to adopt CE. The authors in Ref. [59] have explored the impacts of green practices on financial and operational performances and have concluded that the adoption of green practices (GPs) is conducive to enhance organization environmental performance. Accordingly, companies can increase operational efficiency and reduce the costs associated with waste and energy consumption. It was demonstrated in Ref. [46] that greening the supply chain can positively contribute to a firm's economic performance, reducing costs, and to exploiting new market opportunities. Cost reduction, in particular, is a short-term benefit induced by process innovation [60] and low environmental taxes [61]. Firms can increase revenues mainly due to the introduction of new green products, flows exchange (selling waste as input to another industry) [62], and market reputation effect [16]. In addition, especially considering product-service models, firms can obtain concrete benefits from enhancing relations with customers [63] and improving their customer behavior understanding [64].

The literature highlighted that some of the economic benefits were aligned with environmental benefits. The authors in [65] estimated that firms adopting process innovations based on Industry 4.0 investments can decrease their emissions by up to $30 \%$ and get a positive side effect on demand of up to $20 \%$. Considering that "Circular economy draws from the purest values of CSR and puts them to practice" [66], both CE and CSR can help achieve the sustainable development goals for citizens, institutions, and corporations. An effective corporate commitment to involving stakeholders, shown in Ref. [66], can have relevant implications in terms of CSR reporting, since companies maintain a continuous and interactive dialogue with their stakeholders to obtain their support and positive engagement.

Moreover, many studies have shown that, throughout CSR activities, firms can obtain favorable consumer awareness and attitudes with also positive effects on corporate image and reputation in the long run $[67,68]$. In the case of voluntary environmental disclosures, companies can benefit from positive impacts even with poor performances. Corporate reputation, in particular, is a result of the company's management actions and behavior and CSR engagement can be a particularly effective to build reputation as a form of strategic investment [69] and gain competitive advantage. Beyond companies' initiatives and reporting, governments can have an active and crucial role. Governmental initiatives relate to removing barriers, shaping markets, influencing behaviors, and promoting public demand for sustainable products [70]. All this can translate into appropriate policies and guidelines and more concretely, into strategic plans and incentives that can provide a financial support to companies for CE implementation and environmentally oriented innovation. In this context, the European Commission, with the European Green Deal's Investment Plan and a specific "Circular Economy Action Plan", will mobilize public and private funds to promote initiatives for the transition towards circular practices and green economy [71].

In the end, considering the need to further investigate the potential opportunities offered by the $\mathrm{CE}$ implementation and the importance of having concrete proof of them, the fifth research question is:

RQ5. What are the main opportunities for firms through circular economy?

\subsection{Conceptual Framework}

Starting from the literature review, the conceptual model displayed in Figure 1 has been developed to provide a theoretical background to answer to the research questions. 


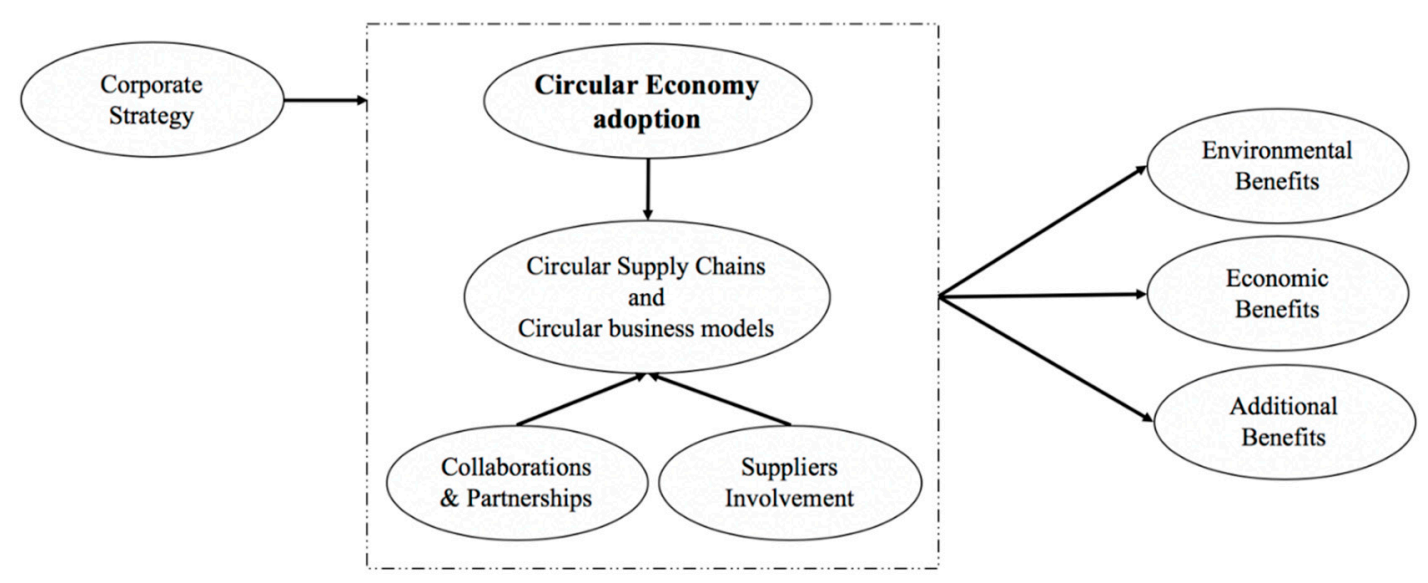

Figure 1. Conceptual Framework.

\section{Methodology}

To answer the research questions $1-5$, a multiple case study approach was adopted. This method allows a flexible data collection, appropriate for analyzing supply chains and managerial issues through empirical enquiries [72,73]. This method is appropriate to address qualitative questions such as "how" in the research process [74], also enabling a holistic and in-depth investigation. Following the recommendation of Ref. [75], four stages were followed in the case study implementation: designing the case study, conducting the case study, analyzing the evidence, as well as developing conclusions, recommendations and implications, as detailed in Figure 2.

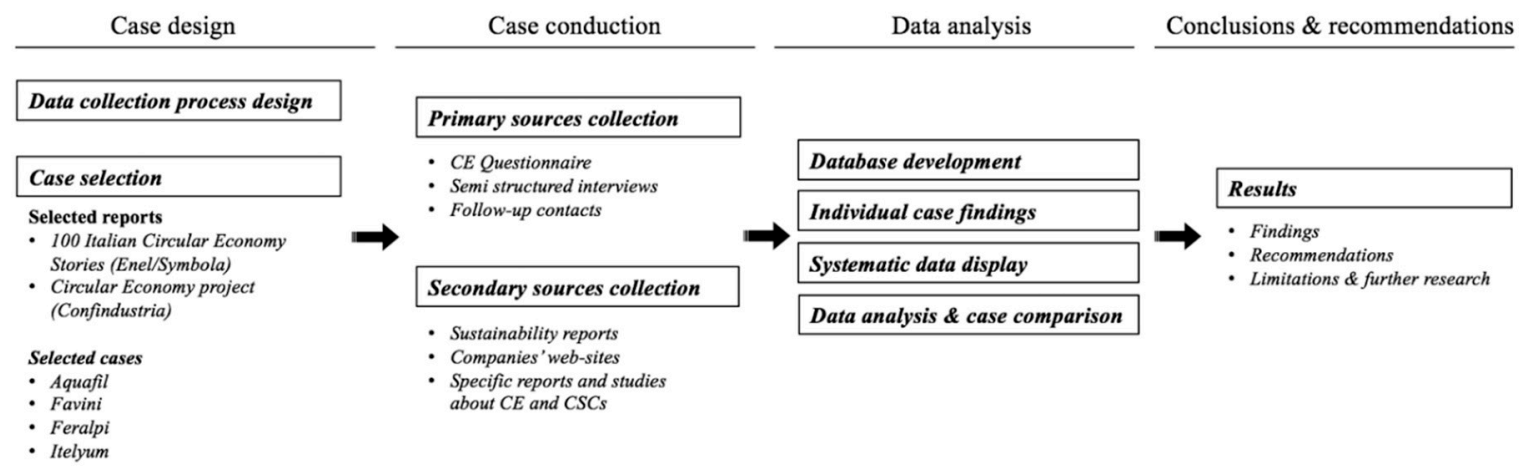

Figure 2. Research design about Circular Economy (CE) and Circular Supply Chain (CSC).

\subsection{Case Selection}

This study concentrated on one country to have more homogenous results and as it was considered desirable before moving to a wider European analysis. Italy was selected as it is the country that, according to "The Circularity Economy Update", that provides an overview of CE in Europe, is among the countries with the highest compounded ranking for CE implementation.

To pursue the objectives of our study, two main sources were used as a starting point for the analysis: the "100 Italian circular economy stories" produced by Enel/Symbola [74] and the "Circular Economy" project by Confindustria in 2019. Enel S.p.A. is an Italian multinational energy Group and one of the main global integrated operators in the electricity and gas sectors. Symbola is an Italian foundation, networking different subjects in politics, economy and institutions, focused on sustainability. Confindustria is the main organization representing Italian manufacturing and service companies. A first set of companies has been selected from the ones listed in the two studies, including the ones producing a sustainability report or having a comprehensive $\mathrm{CE}$ section in their corporate website. A subset of exemplary companies, operating in various industrial sectors, have been preliminarily contacted and the final selection of the cases has been done focusing on those companies 
having implemented more interesting and successful CE models. Given the variety of industrial sectors represented and the diversity of sustainable activities being performed, the cases were selected from four different industrial sectors. Table 1 provides an overview of the case studies under analysis.

Table 1. Case companies overview.

\begin{tabular}{|c|c|c|c|c|}
\hline & AQUAFIL & FAVINI & FERALPI & ITELYUM \\
\hline Industrial sector & Textile industry & Paper industry & Steel industry & $\begin{array}{l}\text { Materials regeneration and industrial } \\
\text { waste management industries }\end{array}$ \\
\hline Type & Manufacturer & Manufacturer & Manufacturer & Manufacturer \\
\hline Revenues & 549 million $€$ & 160 million $€$ & 1302 million $€$ & 300 million $€$ \\
\hline Main CE ouput & $\begin{array}{l}\text { Regenerated and } \\
\text { infinitely recyclable } \\
\text { nylon }\end{array}$ & $\begin{array}{l}\text { Ecological paper from } \\
\text { the creative reuse of } \\
\text { industrial waste }\end{array}$ & $\begin{array}{l}\text { Steel from scrap, } \\
\text { by-products and additives } \\
\text { from production waste }\end{array}$ & $\begin{array}{l}\text { Regenerated waste oil, recovered } \\
\text { exhausted pharmaceutical streams, } \\
\text { hazardous waste valorization }\end{array}$ \\
\hline
\end{tabular}

\subsection{Data Collection}

Both primary and secondary data were used in conducting the study. The secondary data include the two aforementioned studies, providing an extensive set of companies active in the Italian CE context, the companies' sustainability reports and websites as well as national and European reports about CE and environmental issues such as the EU Environmental Implementation Review 2019, Country Report-ITALY" [71] and the "The Circularity Economy Update". Primary data are made of the information collected through a specific questionnaire followed by semi-structured interviews and further follow-up contacts for clarifications and additional details. We interviewed professionals linked to the area of environmental management as well as managers and experts occupying positions in the business units specialized in green strategies. The open-answer questionnaire has been conceived to collect a wide set of information and insights about CE adoption and CSC implementations, within different industrial sectors.

\subsection{Data Analysis}

As suggested by Ref. [75], multiple sources of evidence have been used to ensure and construct the study validity. The triangulation of the questionnaire and interviews outcome has been performed with the secondary data sources. Initially, the information collected was structured in a database to enable an overall overview of the Italian CE scenario. Then, the information gathered from the questionnaire and the interviews was integrated with the data from the companies' reports and websites and organized into four individual case files. In view of the conclusion drawing, data reduction and display were implemented selecting only the most significant content and organizing it in a matrix format. In addition, the displayed data supported comparative analysis and conclusions.

\section{Case Description}

\subsection{Aquafil}

Aquafil is a leading international player in the production of premium synthetic yarns and polymers operating mainly in Europe, US and Asia. Founded in 1965 (Arno, Italy), the company is listed on the Milan Stock Exchange since 2017 and in 2019 it recorded EUR 549 million in revenues. Starting from standard caprolactam, obtained from oil derivatives, and ECONYL caprolactam, internally produced from pre- and post-consumer waste, Aquafil's main product areas are:

- Bulk continuous filament (BCF): flooring solutions for contract, automotive and residential markets;

- Nylon textile filament (NTF): textile solutions for clothing and fashion, swimwear and sportswear sectors;

- $\quad$ Engineering plastics (EP): polyamide and polyester polymer plants for compounders.

Since the 1990s, Aquafil has demonstrated a strong commitment to the CE; developing high-quality products from recovered resources and launching many circular projects. The most important result of 
CE adoption by Aquafil is ECONYL ${ }^{\circledR}$, a regenerated and infinitely recyclable nylon that has the same quality characteristics and performances as the virgin nylon and with a much lower environmental impact. ECONYL ${ }^{\circledR}$ is obtained from pre- and post-consumer waste (such as fishing and aquaculture nets, old carpet, textile and plastic industry waste) through an innovative patented regeneration process, the ECONYL ${ }^{\circledR}$ Regeneration System (Figure 3).

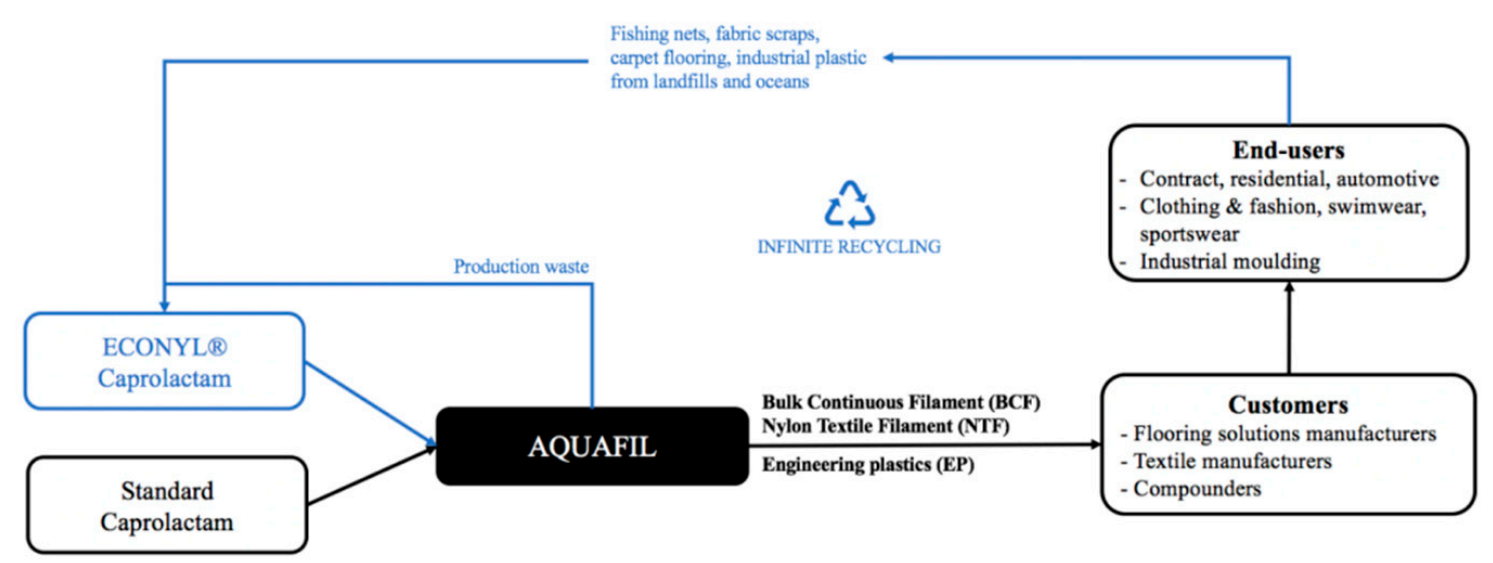

Figure 3. Aquafil's process.

The adoption of CE in Aquafil is part of a specific corporate strategy, supported by the shareholders, which has defined a set of internal principles (ECO PLEDGE) to guide and inspire the work of the company towards excellence and innovation with the commitment to sustainability.

Within the ECONYL Regeneration System, Aquafil has activated the ECONYL ${ }^{\circledR}$ Reclaiming Program, a reverse supply chain system for waste recovery. On the one side, it involves net producers, fishing and aquaculture industries and other players involved in the sorting and selection of the materials; on the other, in terms of carpets and rugs, Aquafil has developed a partnership with Tarkett for using their innovative technology to separate carpet tiles at the end of their life cycle into their two main components (yarn and its backing) maintaining over $95 \%$ yarn purity. Moreover, Aquafil has created two plants in the US entirely dedicated to the recycling processes (deconstruction and fractionation). In addition, Aquafil has recently launched take-back programs with big fashion players such as Napaijri, Gucci and Speedo.

The Bio-Nylon initiative has been activated, since 2017, through a multiyear cooperation with Genomatica Inc. aiming at using only renewable plant-based materials, replacing those derived from crude oil. At the same time, Aquafil started the coordination of the EFFECTIVE project, one of the main industrial initiatives in the bio-nylon field, financially supported by the European research program H2020.

An industrial symbiosis initiative was initiated by AquafilSLO, a company of the group, which gives excess thermal energy to the Atlantis water park in Ljubljana, reducing the impact and the energy waste of its activities. Since 2016, Aquafil is also implementing the ECONYL ${ }^{\circledR}$ Qualified Programme for the development of an environmental qualification protocol for suppliers. The program defines the required environmental criteria in terms of material usage and production process management to reduce the impact of the whole ECONYL ${ }^{\circledR}$ supply chain.

Moving from traditional products to ECONYL ${ }^{\circledR}$, Aquafil, as certified by an external LCA study, has obtained an $80 \%$ reduction in the greenhouse gas emissions generated by the production of raw material and has also regenerated a great amount of waste material that would otherwise be landfilled or end up polluting the environment. Moreover, around the $70 \%$ of the Group's total consumption of electricity and thermal energy comes from renewable sources. In terms of economic benefits, the implementation of $\mathrm{CE}$ has been inspired by a long-term vision that has enabled Aquafil to match the growing demand of sustainable products and achieve company growth and market penetration. 
Current developments include: the replacement (by 2021) of all nylon used by Prada with ENONYL ${ }^{\circledR}$, the first circular economy jacket by Napapijri, the new special line of rugs by Sarawagi Rugs and the new sunglasses collection by Karün.

\subsection{Favini}

Favini is a worldwide leader company in the design and production of textile and finishing solutions for fashion, luxury, design, IT, and technical sportswear sectors. Favini also makes stationary for the leisure and high-end office market. With around EUR 160 million in revenues, its roots can be traced back to 1906 when the Favini family purchased an old paper factory (1736) in Rossano Veneto. Since the 1990s, Favini has paid attention to ecology and environmental protection. Initially, the company introduced the Alga Carta, a special paper containing algae, created to use the build-up of algae that was harming the ecosystem of the Venetian Lagoon. Subsequently, Favini has become specialized in manufacturing paper using industrial scraps/residues and is now a leading global producer of graphics specialties, based on natural fibers, for the packaging of luxury and fashion industries. The main outcome of $\mathrm{CE}$ adoption by Favini is the paper obtained from the creative reuse of industrial residues from other supply chains (agro-industrial, leather, and textile sectors). These practices have led to the development of specific paper product lines:

- Shiro Echo: produced with $100 \%$ recycled fibers;

- Tree Free: made with fibers from annual plants such as bamboo and cotton linters;

- $\quad$ Alga Carta: produced with algae coming from at-risk lagoon environments;

- Crush: produced with 15\% cellulose from agro-industrial by-products (corn, citrus, kiwi, olives, almonds, hazelnuts, coffee, lavender, cherry and grapes);

- $\quad$ Refit: made with $15 \%$ by-products from wool and cotton textile processing;

- Remake: containing $25 \%$ of leather offcuts and shavings.

Since the 1990s, CE adoption has been an important element of the corporate strategy. Favini started out by implementing the circular model when the demand for ecological paper was practically zero and companies were not yet geared towards sustainable supply chains (see Figure 4 for all details). Favini indeed is now able to reap the benefits of having been a first mover and can boast important results, compared to other companies in the sector that are still mainly involved in pilot projects.

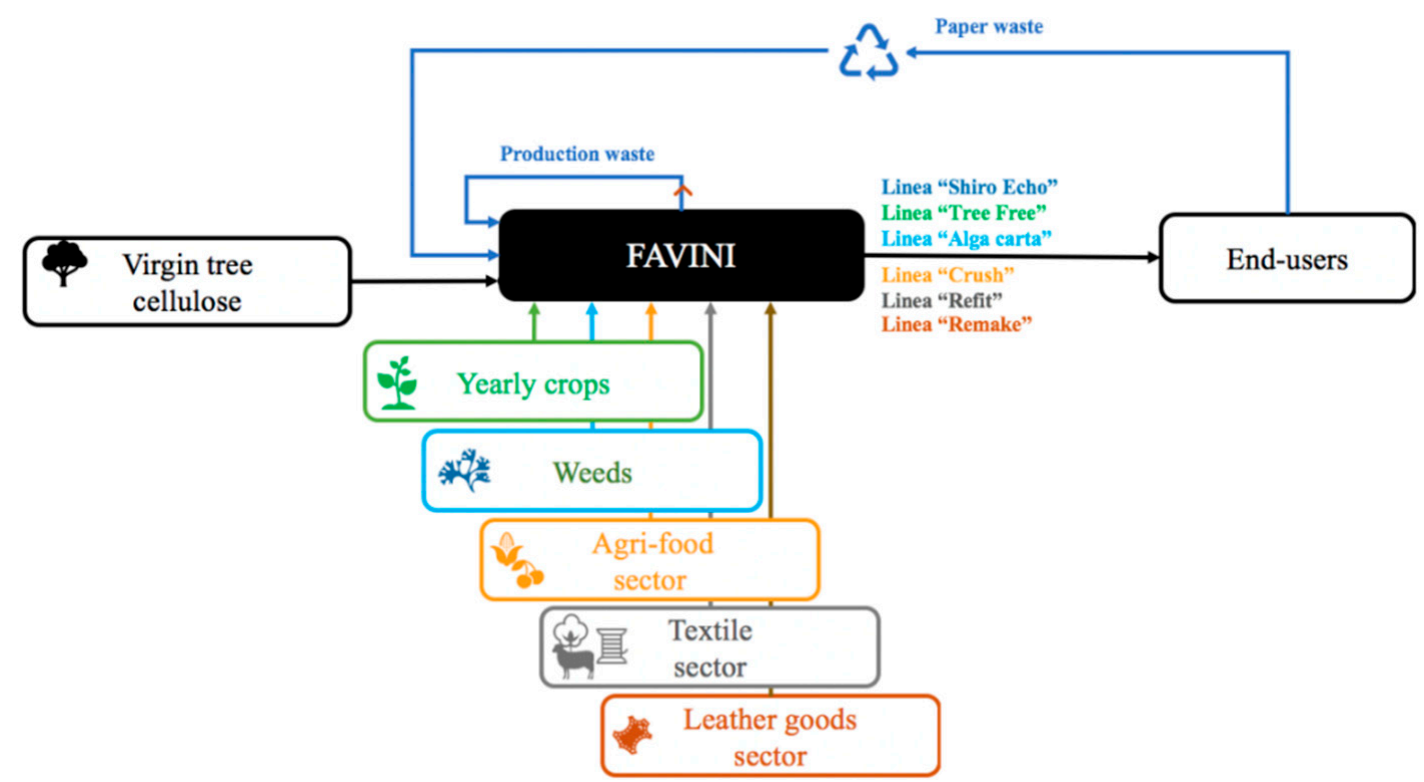

Figure 4. Favini's process. 
Driven by the search for alternative solutions to use by-products and residues as raw materials for the production of low environmental impact papers, Favini invested a lot in research to fully apply the upcycling process. In this context, Favini has built an important partnership with Barilla. From a joint R\&D activity they have created the "Carta Crusca", the first fine paper made from bran residues $(20 \%)$. In addition, Favini produces other ecological papers such as Refit Wool, Refit Cotton and Remake, deriving from industrial symbiosis programs with the textile and the leather sectors as well as from partnerships for fiber processing. Refit Wool and Refit Cotton papers are made using scraps/residues from wool and cotton spinning processes consisting of fibers that, due to their short length or other inadequate characteristics, are discarded. All these textile scraps are of Italian origin and do not require the use of additional chemicals. Remake paper is produced from leather residues; shavings occurring at the tanning phase and scraps from the manufacturing process. Even these products are all from traceable Italian origin, ensuring the use of vegetable tanning and free from chromium/metals.

The excellent results achieved have allowed Favini to collaborate with important brands of the fashion industry (Benetton, Vivienne Westwood, Louis Vuitton) to create ecological packaging for specific product lines. Favini is also supporting circular projects such as Circo, for valuing the waste deriving from coffee roasting, and HUB\&SPOKE, for a new business model in the post-consumer management of hygienic absorbent products (AHP) in Europe.

From the environmental point of view, the main benefits are deriving from the exploitation of residues that would otherwise need to be removed. In addition, since the beginning of this sustainable path (2009), Favini has reduced its water consumption by $40 \%$ thanks to the implementation of a closed water cycle system, it has reduced $\mathrm{CO}_{2}$ emissions by $21 \%$ with $4,920 \mathrm{t} / \mathrm{CO}_{2}$ eq prevented thanks to the self-production of hydroelectric energy and has reduced the energy consumption by $15 \%$ through the continuous investment in energy efficiency. The main economic advantages are linked to the cost of raw materials; for algae and agro-food products, costs are lower than cellulose. Other resources such as leather, instead, have higher costs and imply the application of a mark-up by the company; however, they enable the production of premium products, providing higher sensory experiences to customers, and opening up new markets.

\subsection{Feralpi}

The Feralpi Group is one of Europe's leading manufacturers of steels for the building construction industry. The parent company Feralpi Siderurgica was set up in 1968 in Lonato del Garda (BS); over the years, the company has grown to form a group of companies that in 2019 has recorded revenues of EUR 1302 million with presence in Europe and North Africa.

The main markets and related products are:

- Building construction industry: bars and rolls for reinforced concrete used in the construction of load-bearing structures, as well as spacers and pylons used in the formation of walls and prefabricated structures.

- Manufacturing industry and industrial applications: pre-worked steel products, premium quality steel intermediate products and services concerning the pre-processing of steel products.

Since the very beginning, Feralpi has focused not only on producing high-quality steel but also on doing it in the most sustainable way. The Feralpi Group has become a benchmark for circular economy thanks to its steelmaking production cycle with its electric arc furnace and through a steel from scrap approach, considering its durability, steel can be reused numerous times without losing its intrinsic properties. In addition, the Group recovers various production waste (black slag, refractory materials, non-ferrous metals, dust and flue gases, rolling scale) transforming it into various by-products and additives for construction. See Figure 5 for all details. 


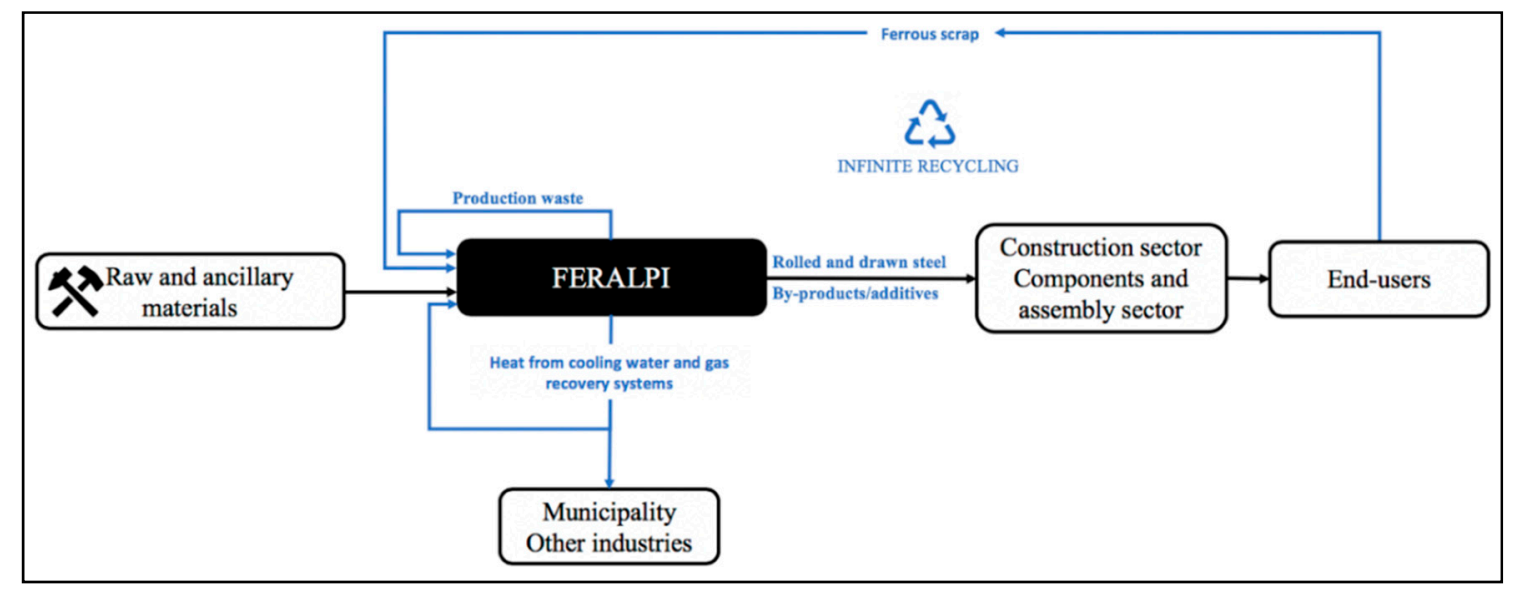

Figure 5. Feralpi Group's process.

Sustainability is an important element of the governance model adopted by the Group and is one of the five pillars of its business strategy. Moreover, the Group has the specific "Sustainability and External Relations" Unit that responds directly to the Group's chairman and interfaces with all the Group's operations.

Specific recovery programs have been implemented by Feralpi for various production wastes and for the re-use of the heat generated. Black slag is used to produce Greenstone, through a specific treatment process developed with and operated by an external specialized partner, and rolling scale is used to produce Green Iron, sold to plants specialized in the production of ballasts and concrete. Heat recovered from the cooling water system and the flue gases of the Riesa (Germany) still mill is partly provided to the Goodyear Dunlop Tires and partly used to generate electricity. Heat recovered from the Feralpi Siderurgica (Italy) still mill is instead used to heat the buildings inside the plant and some public and residential buildings in town.

The Group has also implemented various R\&D projects co-funded by the EC Horizon 2020 Programme. The Fissac project developed "Ecocemento" and "Green Concrete", the first products obtained from the combined recovery of white and black slag for the building construction sector.

Moreover, Feralpi has built a partnership with an external company for the co-development of the slag treatment process for the Greenstone product and is pursuing the development of new methods for recycling plastic/polymers materials to be used as reducing agents instead of coal into their electric arc furnace. The RimFoam project has demonstrated the re-use of car fluff obtained from car demolition while the OnlyPlastic project is pursuing the re-use of waste obtained from recycled packaging.

The quality of the scrap used in their process is a priority for the Group, which purchases only from authorized national and foreign suppliers. In particular, the Group adopts the TenP Sustainable Supply Chain Self-Assessment Platform, a digital platform created by Global Compact Network Italia, with the aim to create a company vendor list for selecting the most responsible suppliers. Feralpi steel production from recycled materials has reached $93.4 \%$ of the total production with consequent environmental benefits in terms of the minimization of the waste produced, prevented raw materials extractions, and reduced landfill from end-of-life steel products. Developments of new methods for recycling plastics/polymers also contribute to reducing waste from other sources.

Economic benefits deriving from Feralpi CE adoption include the reduction in the cost of basic raw materials and additives as well as the cost of the landfilling of waste that would be higher than recycling. In addition, thanks to its commitment towards sustainability, Feralpi has been able to access new green financial tools to support its business development. Feralpi is the first Italian steel manufacturer that obtained the sustainability-linked loan provided by BNL Gruppo BNP Paribas: a credit line of EUR 20 million, with conditions linked to specific, measured, and monitored sustainability targets. 


\subsection{Itelyum}

Generated by the synergic union of 16 well established companies, Itelyum is an international leader in the regeneration of waste oil, the purification of chemical and oil streams, and the responsible management of industrial waste. It operates internationally in Europe, Asia, Africa and the U.S., and in 2019 it recorded EUR 300 million in revenues.

Itelyum has built an integrated and sustainable offer, based on various symbiosis patterns, where the Group implements the CE model through recycled products, responsible waste management, and the supply of products from virgin streams to customers who are also suppliers of the waste to be recycled within the group's plants.

In particular, the $\mathrm{CE}$ is concretely implemented across its three business areas, managed by three specific subsidiaries:

- The regeneration of waste oils. Starting from used lubricating oils and recycling processes, Itelyum produces new lube-based oils and other valuable fractions to be returned to industrial cycles (Itelyum Regeneration Solutions);

- The recovery of spent solvent streams from pharmaceutical chemistry that, after advanced distillation phases, are returned to the same company in a close partnership (Itelyum Purification Solutions);

- The valorization of organic waste streams from different sources to engineer products for other markets (Itelyum Environment Solution).

Guided by a proactive management and supported by its reference shareholder, Stirling Square Capital Partners, Itelyum has made sustainability its strategic foundation targeting the implementation of an advanced CE model, through a fully integrated and sustainable supply chain. See Figure 6 for all details.

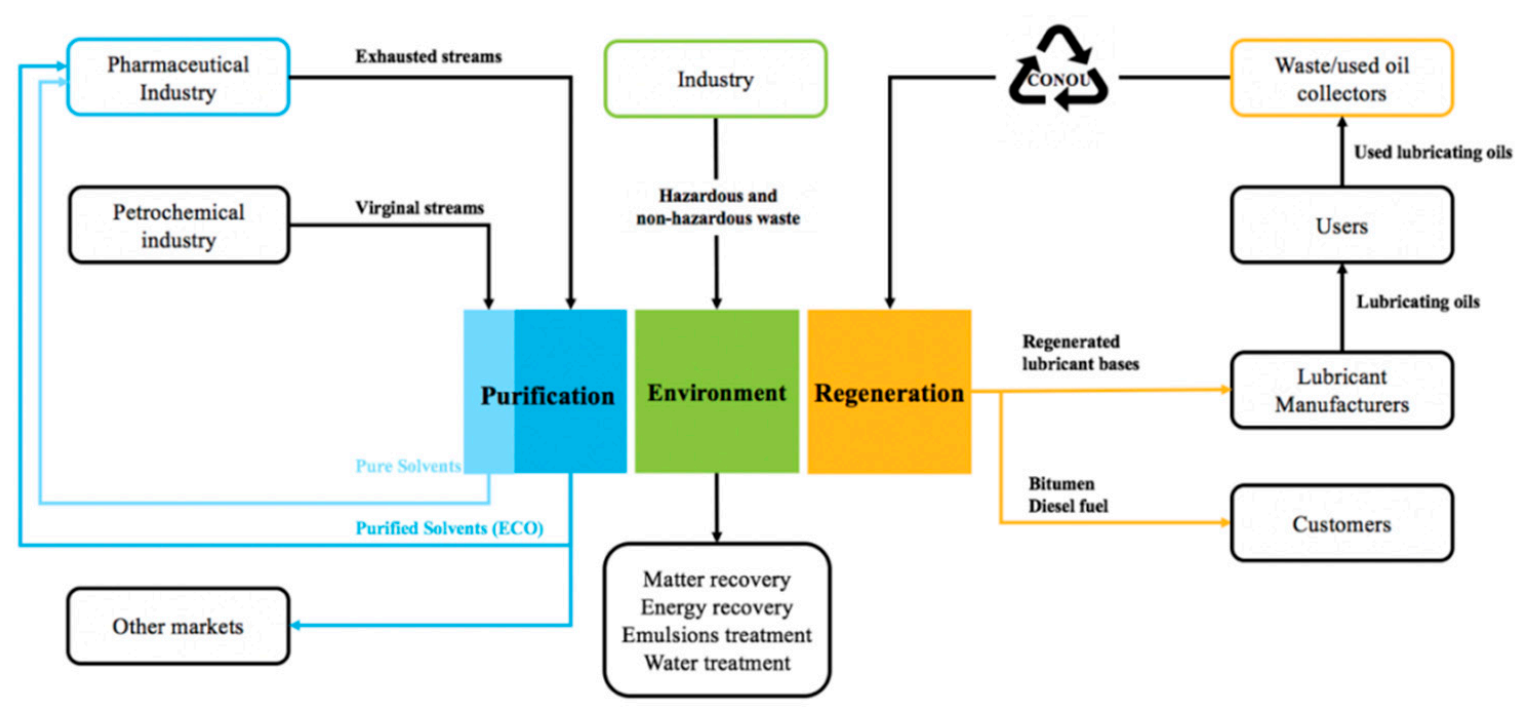

Figure 6. Itelyum's Process.

In the waste oil regeneration sector, Itelyum Regeneration Srl, in solid collaboration with the French company Axens, has developed an innovative process to regenerate the used lube oil providing the highest levels of product quality and environmental performance. Moreover, the Group adheres and works closely with the National Consortium for the Management, Collection and Treatment of Used Mineral Oils (CONOU). The good results achieved in the waste oil collection makes Italy the best performer in Europe and a clear concrete reference for a CE model.

In the sector of the recovery and purification of spent solvents and chemical/pharmaceutical waste streams, Itelyum Purification Srl has built strong partnerships with important players in the 
pharmaceutical/petrochemical industries for the implementation of symbiosis relations with the pharmaceutical and fine chemical sectors.

Itelyum Environment Srl offer a comprehensive range of environmental services in the sector of hazardous waste through the coordination of 13 companies and a network of partners.

Suppliers are an integral part of the Itelyum production and organizational process and are carefully selected in order to offer the highest possible guarantees in terms of quality, safety and environment. The company is evaluating the adoption of the TenP Sustainable Supply Chain Self-Assessment Platform created by the Global Compact Network Italia Foundation, of which they are members, with the aim of supporting companies in the self-assessment of their sustainability strategies and performance.

In environmental terms, by extrapolating the LCA results, Itelyum CE activities supported the responsible valorization of waste coming from other production cycles and helped to prevent the emission of almost 500,000 tons of $\mathrm{CO}_{2}$, the release of more than 1000 tons of air pollutants, the withdrawal of almost 15 million $\mathrm{m}^{3}$ of water and the consumption of more than 400 hectares of land.

These environmental benefits are also linked to lower production costs, in terms of less energy consumed, with the possibility of bringing more competitive products to the market compared to those from the production of virgin raw materials. Itelyum has also performed an integrated P\&L analysis that assessed a net value of about EUR 30 million of externalities, about EUR 40 million of internalized economic value and the same amount in EUR of socio-economic value. Recently, they have extensively evaluated their "circularity" using the Circulytics protocol developed by the Ellen MacArthur Foundation, obtaining a level A score on a scale from E (worst) to A+ (best). In addition, the Group uses an internal circularity index to evaluate the mass balance between the input and output towards value destinations, such as recycling, recovery and waste water depuration.

\section{Analysis and Comparison of the Cases}

In line with the five RQs, a comparative analysis was conducted, with all details displayed in Appendix A. This analysis has been done with the aim of finding the main similarities and differences in terms of CE adoption and consequent CSC implementation. To provide a more detailed and consistent analysis, each research question has been broken down into more specific parameters/dimensions.

The four companies have all implemented new CE solutions in view of the principles of durability, renewability, reuse, and reduced material. This implies new goods/services, new/significantly improved production/logistic/recycling processes and/or a fully circular business model based on a new value creation logic. Moved by these same principles, their outputs differ considering the industrial sector, the size, and the adopted business model. Appendix B summarizes the results and provides an overview of the main findings.

Our results show that many companies are ready to renew themselves by developing CE solutions that align their economic and sustainability objectives. In recent years, networks, best practice exchanges, public/private alliances, as well as awareness-raising initiatives have proliferated. The European Union has made an excellent start, but the pace of change differs among the member states and is largely determined by the initiatives activated by each country. Italy performs very well in terms of CE economy indicator rankings, as stated by the EU's monitoring framework for a CE and by the European Federation of Sustainable Business.

The four selected cases are in line with the overall Italian scenario and offer additional in-depth understanding of the initial expectations and drivers, the progressive introduction of CE principles and their concrete implementation through CSCs.

\subsection{Circular Economy Role within Corporate Strategies}

CE implementation requires huge investments, cultural/organizational changes, and offers economic benefits that are not always easily predictable and quantifiable. Therefore, there is a need for a clear company vision, shared between company owners, and top management. These elements identify the CE potential and motivate its adoption to achieve efficiency and growth along with 
competitiveness and improved reputation. In each company, CE has an important role in defining the corporate strategy; in all cases, the top management has created a strong path towards $\mathrm{CE}$, integrating new objectives, looking for fresh financial resources, sponsoring the industrial symbiosis, and guiding both the cultural and the organizational changes.

Itelyum has made sustainability its strategic axis developing an advanced fully circular business model. Aquafil has chosen sustainability to stay at the forefront of its sector and has re-designed its processes with a circular perspective; all is realized by integrating and using recovered raw materials. Feralpi, operating in a sector with low product differentiation, has strategically decided to make sustainability its distinctive competitive advantage by making innovative products derived from its industrial scraps. In the end, Favini has transformed the algae reuse activity aimed at restoring the lagoon environment into an innovative new business in high-end market segments, by extending the same principle to produce ecological paper with other industrial scraps.

The direct involvement of top management is key for redefining relations with the main SC actors and establish collaborative industrial partnerships. Suppliers, partners, and all internal organization units must all be aligned in an integrated CSC guided by a common vision and strategic collaboration. Itelyum is a perfect example; born circular, it has developed an integrated and sustainable offer of products, solutions, and services. Aquafil, main the adoption of $\mathrm{CE}$, encountered more difficulties than expected and only the firms' commitment enabled the successful implementation of the CSC.

These findings allow us to identify a first proposition:

Proposition 1. The implementation of CE requires strategic decisions and commitment by the shareholders and the top management, to identify new business opportunities, promoting an integrated CSC, and guiding both the cultural and organizational changes required to accommodate CE principles.

\subsection{Circular Supply Chains, Innovation, and Suppliers' Selection}

$\mathrm{CE}$ requires and can be fostered by new technologies and innovation strategies. Innovation deriving from the implementation of $\mathrm{CE}$ can require the introduction of new products and/or the implementation of new processes, with the objective to reuse the waste and scraps generated either internally or by other industries (industrial symbiosis), support new business opportunities (reach new markets and businesses), and improve the firm's overall efficiency (lower energy consumption, usage of virgin material, waste). In particular, the innovation linked to CE need collaborative and joint programs with CSC partners to be realized by combining technologies, knowledge, and cultures. These synergic processes continuously stimulate companies to select suppliers that have an aligned CE strategy.

Aquafil has developed an innovative technology to recover carpet tiles and a process to use only renewable plant-based materials for the Bio-Nylon production. Favini has created a new fine paper from the agro-industry. Feralpi has achieved higher process efficiency and has developed new by-products. Itelyum has developed an innovative process to regenerate the used lube oil with high quality and performance levels, also for the pharmaceutical sector.

Cross-cycles and cross-sectoral activities are two important common practices: industrial scraps and waste can in fact enter different cycles or different SCs with respect to where they were generated. All the cases present high performing resource-recovery systems, Feralpi using iron scrap and internal production residues, the others (Aquafil, Favini, Itelyum) exploiting scraps coming mainly from other industries. In particular, Favini successfully reuses scraps coming from the agri-food and the textile industry, Aquafil uses fishing/aquaculture nets, old carpet, textile and plastic industry waste, Itelyum instead operates with partners from the pharmaceutical and oil sectors.

These forms of structured collaboration that involve the use of a company in another industry sector waste as an input, take the form of industrial symbiosis networks on a long-term basis and reduce both waste disposal and material requirements. Firms create a "circular ecosystem" by involving CSC partners and collaborating with all stakeholders to create a harmonious framework where CE 
programs and practices function effectively. In particular, suppliers can strongly influence the level of sustainability of the final product and service, implying pressures for acquiring ad hoc certifications and providing evidence of their environmental commitments. Three out of the four companies analyzed have introduced specific supplier selection protocols with a particular focus on product traceability and environmental certifications; Aquafil and Itelyum rely on internal suppliers' evaluation systems, while Feralpi uses the TenP platform.

These findings allow us to get a second proposition:

Proposition 2. Green technologies and eco-innovations are the core of a CSC and imply collaborative programs with partners and stakeholders to successfully manage the industrial symbiosis.

\subsection{Circular Economy Benefits and Opportunities}

The European Circular Economy Action Plan identifies CE as an essential element of a broader transformation towards climate neutrality and long-term competitiveness. Indeed, CE makes it possible to combine environmental sustainability with economic sustainability.

The comparative case analysis shows that the main environmental benefits obtained by the companies are resource recovery from waste regeneration and exploitation, resource efficiency (water and energy consumption), circular inputs, and the reduction in $\mathrm{CO}_{2}$ emissions.

In terms of economic benefits, the main returns are: raw material cost reduction and increased processes efficiency, new markets penetration and business opportunities, as well as access to green financial opportunities and funding programs. By adopting CE principles, Favini has remarkably reduced the use of virgin material and consequently, its raw material costs; Feralpi has improved resource efficiency within its production processes as well as at a system level, resulting in a highly successful CE strategy through which it has obtained financial grants from BNL (BNP Paribas). Thanks to the adoption of CE programs, Aquafil and Itelyum acquired EU funding by means of which they launched new eco-innovation projects to strengthen their CE even more.

Additional benefits from CE adoption include: innovation, cooperation opportunities, and public funding, as well as improved competitiveness, brand differentiation/reputation, and a deeper relationship with existing customers. Aquafil and Itelyum gained competitive advantages by increasing their market share and drive the transformation as leaders; Feralpi exploited their CSC by enabling their clients to achieve high scores in public tenders; Favini obtained brand recognition from new market penetration, in particular from accessing the luxury and fashion sectors. To implement $\mathrm{CE}$, the companies necessarily introduced green technologies and eco-innovation, and making partnerships and CSCs at the same time. Therefore, CE activates technological development, innovation strategies, and partnerships, all substantially contributing to achieve high outcomes and performance targets. These findings allow us to identify the third and last proposition:

Proposition 3. Along with environmental benefits, CE grants positive economic outcomes in terms of cost savings and efficiency and opens up new business opportunities ensuring long-term competitiveness and growth.

\section{Conclusions}

In this study, we investigated the modern ways for implementing a successful circular economy (CE) program considering its relevance for supply chains, corporate strategies, and industrial symbiosis. Our findings demonstrate that $\mathrm{CE}$ is a real business accelerator as it grants the opportunity for companies to improve their environmental impact and social contribution as well as to discover new and atypical business opportunities by engaging top management and shareholders, supply chain members, industrial partners, and consumers.

We carry out a comparative case study by identifying companies emerging in secondary reports and research projects as excellence in the area of $\mathrm{CE}$. We then select four companies that have successfully implemented CE programs, to discover the secrets for successfully adopting CE programs. Therefore, 
we seek to complement the existing body of knowledge in the literature, which provides limited practical and real evidence and the analysis of CE.

The companies that we analyzed started adopting CE several years ago, when CE was not yet a hot topic, and they have been guided by a clear vision and the commitment of their shareholders and top management. In fact, the successful implementation of CE requires the support of a long-term vision and the full engagement from top management; the latter should effectively communicate the new strategy and manage both a cultural and an organizational transformation that also include the stakeholders, partners, and consumers. Our findings reveal that firms should extend the applicability of a CE to further products and processes by expanding their business horizons, collaborating with circular supply chain partners, establishing strong industrial symbiosis, and be heavy eco-innovators. Overall, firms can obtain benefits from CE programs by embracing a "circular thinking" approach extended to the entire eco-system. This allows firms to achieve savings and exploit new business opportunities, along with creating an environmentally and socially sustainable business.

The study analysis focuses only on four Italian companies in different industrial sectors. To overcome this limitation, a wider analysis could consider a larger number of companies to provide more generalized findings, while performing a cross-country analysis could lead to a more comprehensive comparison of the $\mathrm{CE}$ implementation within different national industrial structures and business scenarios. Further research could also explore theoretical methodologies and practical tools for a more systematic assessment of the economic performance achieved by CE programs, to provide reliable feedback for successful managerial plans and decisions.

Author Contributions: Conceptualization, C.M. and P.D.G.; methodology, C.M.; software, C.M.; validation, C.M., P.D.G.; formal analysis, P.D.G.; investigation, C.M.; resources, C.M.; data curation, C.M.; writing-original draft preparation, C.M. and P.D.G.; writing-review and editing, P.D.G.; visualization, C.M.; supervision, P.D.G.; project administration, C.M.; funding acquisition, P.D.G. All authors have read and agreed to the published version of the manuscript.

Funding: This research received no external funding.

Conflicts of Interest: The authors declare no conflict of interest. 


\section{Appendix A}

Table A1. Data collection.

\begin{tabular}{|c|c|c|c|c|}
\hline & $\begin{array}{l}\text { Industrial sector: } \\
\text { - Textile industry }\end{array}$ & $\begin{array}{l}\text { Industrial sector: } \\
\text { - Paper industry }\end{array}$ & $\begin{array}{l}\text { Industrial sector: } \\
\text { - Steel industry }\end{array}$ & $\begin{array}{l}\text { Industrial sector: } \\
\text { - Materials regeneration and industrial waste } \\
\text { management industry }\end{array}$ \\
\hline $\begin{array}{l}\text { How is CE concretely } \\
\text { implemented by } \\
\text { companies? }\end{array}$ & $\begin{array}{l}\text { CE implementation: } \\
\text { - Regenerated and infinitely } \\
\text { recyclable nylon (ECONYL }{ }^{\circledR} \text { ) } \\
\text { obtained from an innovative patented } \\
\text { regeneration process of pre- and } \\
\text { post-consumer waste }\end{array}$ & $\begin{array}{l}\text { CE implementation: } \\
\text { - Creative reuse of industrial } \\
\text { residues/scraps and } \\
\text { development of new specific } \\
\text { ecological paper product lines: } \\
\text { Shiro, Crush, Refit, Remake }\end{array}$ & $\begin{array}{l}\text { CE implementation: } \\
\text { - Steel from scrap } \\
\text { - By-products and additives (Green Stone, Green } \\
\text { Iron) from production waste valorization for the } \\
\text { construction industry }\end{array}$ & $\begin{array}{l}\text { CE implementation: } \\
\text { - Regenerated waste oil } \\
\text { - Recovered exhausted pharmaceutical streams } \\
\text { - Hazardous and organic waste valorization } \\
\text { - Wastewater depuration } \\
\text { - Responsible waste management }\end{array}$ \\
\hline $\begin{array}{l}\text { How does CE relate to } \\
\text { the corporate strategy? }\end{array}$ & $\begin{array}{l}\text { - Multiyear path supported by all the } \\
\text { shareholders and guided by specific } \\
\text { internal sustainability principles } \\
\text { (ECO PLEDGE) }\end{array}$ & $\begin{array}{l}\text { - CE is fully integrated in the } \\
\text { corporate strategy and enables } \\
\text { them to be the first movers in } \\
\text { the paper industry }\end{array}$ & $\begin{array}{l}\text { - Sustainability is a pillar of their business strategy } \\
\text { with a dedicated company organization unit } \\
\text { reporting to the Chairman }\end{array}$ & $\begin{array}{l}\text { - Sustainability and implementation of an } \\
\text { advanced CE model with a circular supply chain } \\
\text { are at the core of their creation }\end{array}$ \\
\hline \multirow{5}{*}{$\begin{array}{l}\text { Which are the } \\
\text { sustainability programs } \\
\text { in the circular supply } \\
\text { chains? }\end{array}$} & $\begin{array}{l}\text { Resource recovery } \\
\text { - Nylon from carpets and rugs for } \\
\text { ECONYL }{ }^{\circledR}\end{array}$ & $\begin{array}{l}\text { Resource recovery } \\
\text { - Wool, cotton, seaweeds, leather } \\
\text { and agro-industry production } \\
\text { scraps (upcycling) }\end{array}$ & $\begin{array}{l}\text { Resource recovery } \\
\text { - Steel scraps } \\
\text { - Production waste (black slag, refractory materials, } \\
\text { non-ferrous metals, dust/flue gases, rolling scale) } \\
\text { - Plastic/polymers materials from various sources } \\
\text { - Recovered heat for buildings inside and outside } \\
\text { the plant }\end{array}$ & $\begin{array}{l}\text { Resource recovery } \\
\text { - Used lubricating oils } \\
\text { - Spent solvent streams from the pharmaceutical } \\
\text { industry } \\
\text { - Industrial waste }\end{array}$ \\
\hline & $\begin{array}{l}\text { Circular input } \\
\text { - Organic material for Bio-Nylon } \\
\text { production } \\
\text { - Energy self-generation from } \\
\text { photovoltaic system }\end{array}$ & $\begin{array}{l}\text { Circular input } \\
\text { - Algae and annual plants for } \\
\text { Shiro paper } \\
\text { - Energy self-generation from } \\
\text { hydroelectric system and new } \\
\text { aeolic system }\end{array}$ & $\begin{array}{l}\text { Circular input } \\
\text { - Energy self-generation from renewable systems }\end{array}$ & $\begin{array}{l}\text { Circular input } \\
\text { - Energy self-generation from high-performance } \\
\text { co-generation } \\
\text { - Energy from fuels recovered from waste streams } \\
\text { - Energy self-generation from photovoltaic system }\end{array}$ \\
\hline & $\begin{array}{l}\text { Specific reclaiming program } \\
\text { - Reclaiming Program for waste } \\
\text { containing nylon } \\
\text { - Take-back programs with big } \\
\text { fashion players }\end{array}$ & $\begin{array}{l}\text { Specific reclaiming program } \\
\text { NO }\end{array}$ & $\begin{array}{l}\text { Specific reclaiming program } \\
\text { NO }\end{array}$ & $\begin{array}{l}\text { Specific reclaiming program } \\
\text { - Wasted oil from automotive and spent solvents } \\
\text { from pharmaceutical }\end{array}$ \\
\hline & $\begin{array}{l}\text { Industrial symbiosis—materials } \\
\text { NO }\end{array}$ & $\begin{array}{l}\text { Industrial } \\
\text { symbiosis-materials } \\
\text { - Creative reuse of } \\
\text { agro-industrial, leather and } \\
\text { textile scraps }\end{array}$ & $\begin{array}{l}\text { Industrial symbiosis-materials } \\
\text { NO }\end{array}$ & $\begin{array}{l}\text { Industrial symbiosis-materials } \\
\text { - Recovery of spent solvent from/for } \\
\text { pharmaceutical industry } \\
\text { - Recovery of waste oils }\end{array}$ \\
\hline & $\begin{array}{l}\text { Industrial symbiosis-energy } \\
\text { - AqualifSLO excess thermal energy } \\
\text { to Atlantis water park in Ljubljana }\end{array}$ & $\begin{array}{l}\text { Industrial symbiosis—energy } \\
\text { NO }\end{array}$ & $\begin{array}{l}\text { Industrial symbiosis-energy } \\
\text { - Recovered heat to buildings inside the plant, to } \\
\text { Goodyear Dunlop Tires and to public and } \\
\text { residential buildings }\end{array}$ & $\begin{array}{l}\text { Industrial symbiosis—energy } \\
\text { NO }\end{array}$ \\
\hline
\end{tabular}


Table A1. Cont.

\begin{tabular}{|c|c|c|c|c|}
\hline $\begin{array}{l}\text { Which are the } \\
\text { sustainability programs } \\
\text { in the circular supply } \\
\text { chains? }\end{array}$ & $\begin{array}{l}\text { Process and product innovation: } \\
\text { - Bio-Nylon from only renewable } \\
\text { materials (e.g., plants) } \\
\text { - New materials and innovative } \\
\text { processes }\end{array}$ & $\begin{array}{l}\text { Process and product } \\
\text { innovation: } \\
\text { - New fine paper from } \\
\text { agro-industry (Carta Crusca, } \\
\text { Crush Cacao, Crush Grape, } \\
\text { Crush Fagiolo) } \\
\text { - Post-consumer absorbent } \\
\text { hygienic products }\end{array}$ & $\begin{array}{l}\text { Process and product innovation: } \\
\text { - First intermediate products obtained from the } \\
\text { combined recovery of white and black slag } \\
\text { (Ecocemento, Green Concrete) } \\
\text { - Re-use of fluff from car demolition } \\
\text { - Recycling of plastic packaging } \\
\text { - product quality and process optimization } \\
\text { - Increase energy efficiency and reduce impact and } \\
\text { emissions, in line with an Industry } 4.0 \text { approach }\end{array}$ & $\begin{array}{l}\text { Process and product innovation: } \\
\text { - Improvement of plants flexibility, making them } \\
\text { suitable for receiving and handling variable and } \\
\text { different charges } \\
\text { - Increase in process transformation efficiency, } \\
\text { optimizing raw materials and waste management }\end{array}$ \\
\hline \multirow[b]{2}{*}{$\begin{array}{l}\text { Which are the main } \\
\text { stakeholders that } \\
\text { contribute to CSC } \\
\text { implementation? }\end{array}$} & $\begin{array}{l}\text { Suppliers selection } \\
\text { - Environmental qualification protocol } \\
\text { for supplier selection (ECONYL }{ }^{\circledR} \\
\text { Qualified Programme) }\end{array}$ & $\begin{array}{l}\text { Suppliers selection } \\
\text { - No specific program but } \\
\text { requirement for no use of } \\
\text { metals, chrome and pollutants }\end{array}$ & $\begin{array}{l}\text { Suppliers selection } \\
\text { - Scrap purchases only from authorized national } \\
\text { and foreign suppliers } \\
\text { - Use of Sustainable Supply Chain Self-Assessment } \\
\text { Platform (TenP) }\end{array}$ & $\begin{array}{l}\text { Suppliers selection } \\
\text { - Internal criteria } \\
\text { - Sustainable Supply Chain Self-Assessment } \\
\text { Platform (TenP) being implemented }\end{array}$ \\
\hline & $\begin{array}{l}\text { Partnerships and collaborations } \\
\text { - Tarkett for an innovative technology } \\
\text { to recover carpet tiles } \\
\text { - Genomatica Inc. to use only } \\
\text { renewable plant-based materials in } \\
\text { the Bio-Nylon production }\end{array}$ & $\begin{array}{l}\text { Partnerships and } \\
\text { collaborations } \\
\text { - Industrial collaborations for } \\
\text { fiber processing } \\
\text { - Fashion industry (Benetton, } \\
\text { Vivienne Westwood, Louis } \\
\text { Vuitton) to create ecological } \\
\text { packaging for specific product } \\
\text { lines }\end{array}$ & $\begin{array}{l}\text { Partnerships and collaborations } \\
\text { - Partnership for the co-development of the slag } \\
\text { treatment process for the Greenstone product } \\
\text { - University R\&D }\end{array}$ & $\begin{array}{l}\text { Partnerships and collaborations } \\
\text { - Axens for an innovative process to regenerate the } \\
\text { used lube oil with high quality and performance } \\
\text { levels } \\
\text { - Chemicals and lubricants industrial sectors }\end{array}$ \\
\hline $\begin{array}{l}\text { Which are the main } \\
\text { environmental benefits } \\
\text { generated by the } C E \\
\text { implementation? }\end{array}$ & $\begin{array}{l}\text { Environmental benefits: } \\
\text { - Waste regeneration and exploitation } \\
\text { (used carpets/rugs) } \\
\text { - Reduction in water consumption } \\
\text { (internal water recycling) } \\
\text { - Reduced } \mathrm{CO}_{2} \text { emissions } \\
\text { - Electric energy from renewable } \\
\text { sources }\end{array}$ & $\begin{array}{l}\text { Environmental benefits: } \\
\text { - Industrial scraps regeneration } \\
\text { and exploitation (from agro and } \\
\text { fashion industries) } \\
\text { - Reduction in water } \\
\text { consumption (internal water } \\
\text { recycling) } \\
\text { - Reduced } \mathrm{CO}_{2} \text { emissions } \\
\text { - Electric energy from } \\
\text { hydroelectric and new Aeolic } \\
\text { project to compensate } \mathrm{CO}_{2} \\
\text { emissions }\end{array}$ & $\begin{array}{l}\text { Environmental benefits: } \\
\text { - Waste regeneration and exploitation (metal waste) } \\
\text { - Reduction in water consumption } \\
\text { - Reduced } \mathrm{CO}_{2} \text { emissions } \\
\text { - Energy self-generation from photovoltaic source }\end{array}$ & $\begin{array}{l}\text { Environmental benefits: } \\
\text { - Waste regeneration and exploitation (used oil) } \\
\text { - Reduced water withdrawal } \\
\text { - Reduced } \mathrm{CO}_{2} \text { emissions and prevented tons of air } \\
\text { pollutants } \\
-700 \text { tons of dangerous waste responsibly managed } \\
\text { - Lower land consumption/pollution }\end{array}$ \\
\hline $\begin{array}{l}\text { Which are the main } \\
\text { economic benefits } \\
\text { generated by the } C E \\
\text { implementation? }\end{array}$ & $\begin{array}{l}\text { Economic benefits: } \\
\text { - Risk mitigation thanks to lower raw } \\
\text { material cost volatility } \\
\text { - Revenues from new market } \\
\text { segments through new eco-products } \\
\text { (ECONYL }{ }^{\circledR} \text { ) } \\
\text { - EU-funded projects }\end{array}$ & $\begin{array}{l}\text { Economic benefits: } \\
\text { - Cost reduction for certain raw } \\
\text { materials } \\
\text { - Revenues from new market } \\
\text { segments (fashion, food, } \\
\text { stationary) through new } \\
\text { premium paper (Crush, Refit, } \\
\text { Remake) } \\
\text { - EU-funded projects }\end{array}$ & $\begin{array}{l}\text { Economic benefits: } \\
\text { - Cost reduction for landfilling } \\
\text { - Access to new green financial tools and EU } \\
\text { funded projects } \\
\text { - Compliance with national regulations }\end{array}$ & $\begin{array}{l}\text { Economic benefits: } \\
\text { - Internalized socio-economic value (sustainable } \\
\text { approach provides success levers for improvement } \\
\text { of turnover and economic margins, mitigation of } \\
\text { enterprise risk, the attraction of capital and } \\
\text { investors and the consolidation of the brand) }\end{array}$ \\
\hline
\end{tabular}




\section{Appendix B}

Table A2. Case comparison and analysis.

\begin{tabular}{|c|c|c|c|c|c|}
\hline Core Questions & Question Items & AQUAFIL & FAVINI & FERALPI & ITELYUM \\
\hline \multirow{3}{*}{$\begin{array}{l}\text { How is CE concretely implemented } \\
\text { by companies? }\end{array}$} & Product innovation & & $\checkmark$ & $\checkmark$ & \\
\hline & Process innovation & $\checkmark$ & $\checkmark$ & $\checkmark$ & $\checkmark$ \\
\hline & Business model innovation & $\checkmark$ & $\checkmark$ & & $\checkmark$ \\
\hline $\begin{array}{l}\text { How does CE relate to the } \\
\text { corporate strategy? }\end{array}$ & $C E$ as a key element in the corporate strategy & $\checkmark$ & $\checkmark$ & $\checkmark$ & $\checkmark$ \\
\hline \multirow{5}{*}{$\begin{array}{c}\text { Which are the sustainability programs in } \\
\text { the Circular Supply Chains? }\end{array}$} & Resource recovery & $\checkmark$ & $\checkmark$ & $\checkmark$ & $\checkmark$ \\
\hline & Circular inputs & $\checkmark$ & $\checkmark$ & $\checkmark$ & $\checkmark$ \\
\hline & Industrial symbiosis—-materials & & $\checkmark$ & $\checkmark$ & $\checkmark$ \\
\hline & Industrial symbiosis—energy & $\checkmark$ & & $\checkmark$ & \\
\hline & $R \mathcal{E D}$ for product/process innovation & $\checkmark$ & $\checkmark$ & $\checkmark$ & $\checkmark$ \\
\hline \multirow{2}{*}{$\begin{array}{l}\text { Which are the main stakeholders that } \\
\text { contribute to CSC implementation? }\end{array}$} & Supplier selection program & $\checkmark$ & & $\checkmark$ & $\checkmark$ \\
\hline & Partnerships & $\checkmark$ & $\checkmark$ & $\checkmark$ & $\checkmark$ \\
\hline \multirow{4}{*}{$\begin{array}{l}\text { Which are the main environmental } \\
\text { benefits generated by the } \\
\text { CE implementation? }\end{array}$} & Waste regeneration and exploitation & $\checkmark$ & $\checkmark$ & $\checkmark$ & $\checkmark$ \\
\hline & Reduced water consumption & $\checkmark$ & $\checkmark$ & $\checkmark$ & $\checkmark$ \\
\hline & Reduced CO2 emissions & $\checkmark$ & $\checkmark$ & $\checkmark$ & $\checkmark$ \\
\hline & Reduced land consumption & & & & $\checkmark$ \\
\hline \multirow{8}{*}{$\begin{array}{l}\text { Which are the main economic benefits } \\
\text { generated by the CE implementation? }\end{array}$} & Cost reduction for raw materials & $\checkmark$ & $\checkmark$ & $\checkmark$ & $\checkmark$ \\
\hline & Cost reduction for landfilling & $\checkmark$ & & $\checkmark$ & $\checkmark$ \\
\hline & Cost reduction for water and energy consumption & limited & limited & limited & $\checkmark$ \\
\hline & Risk mitigation & $\checkmark$ & & & $\checkmark$ \\
\hline & New market segments penetration & $\checkmark$ & $\checkmark$ & $\checkmark$ & \\
\hline & Increased revenues/turnover improvements & $\checkmark$ & $\checkmark$ & limited & $\checkmark$ \\
\hline & Access to green financial tools & $\checkmark$ & $\checkmark$ & $\checkmark(*)$ & $\checkmark$ \\
\hline & Brand consolidation and competitiveness improvement & $\checkmark$ & $\checkmark$ & $\checkmark$ & $\checkmark$ \\
\hline
\end{tabular}




\section{References}

1. Borowski, P.F. Nexus between water, energy, food and climate change as challenges facing the modern global, European and Polish economy. AIMS Geosci. 2020, 6, 397-421. [CrossRef]

2. Kaza, S.; Yao, L.; Bhada-Tata, P.; Van Woerden, F. What a Waste 2.0: A Global Snapshot of Solid Waste Management to 2050; Urban Development; World Bank: Washington, DC, USA, 2018.

3. Vanalle, R.M.; Ganga, G.M.D.; Godinho Filho, M.; Lucato, W.C. Green supply chain management: An investigation of pressures, practices, and performance within the Brazilian automotive supply chain. J. Clean. Prod. 2017, 151, 250-259. [CrossRef]

4. De Giovanni, P.; Zaccour, G. A selective survey of game-theoretic models of closed-loop supply chains. $4 O R$ 2019, 17, 1-44. [CrossRef]

5. Landrum, N.E.; Ohsowski, B. Identifying worldviews on corporate sustainability: A content analysis of corporate sustainability reports. Bus. Strategy Environ. 2018, 27, 128-151. [CrossRef]

6. D'Amato, D.; Droste, N.; Allen, B.; Kettunen, M.; Lähtinen, K.; Korhonen, J.; Toppinen, A. Green, circular, bio economy: A comparative analysis of sustainability avenues. J. Clean. Prod. 2017, 168, 716-734. [CrossRef]

7. Farooque, M.; Zhang, A.; Thürer, M.; Qu, T.; Huisingh, D. Circular supply chain management: A definition and structured literature review. J. Clean. Prod. 2019, 228, 882-900. [CrossRef]

8. Brown, P.; Bocken, N.; Balkenende, R. Why do companies pursue collaborative circular oriented innovation? Sustainability 2019, 11, 635. [CrossRef]

9. Luciano, B.; Bourlakis, M.; Maull, R. Business Models in the Circular Economy and the Enabling Role of Supply Chains. In Proceedings of the 23rd European Operations Management Association (EurOMA), Trondheim, Norway, 17-22 June 2016.

10. Rockström, J.; Steffen, W.; Noone, K.; Persson, A.; Chapin, F.S., III; Lambin, E.; Lenton, T.M.; Scheffer, M.; Folke, C.; Schellnhuber, H.J.; et al. Planetary Boundaries: Exploring the safe operating space for humanity. Ecol. Soc. 2009, 14, 32. [CrossRef]

11. Meadows, D.H.; Randers, J.; Meadows, D.L. The Limits to Growth. The 30-Year Update; Routledge: London, UK, 2004.

12. Reeves, M.; Deimler, M. Adaptability: The new competitive advantage. In Harvard Business Review; John Wiley \& Sons, Ltd.: Hoboken, NJ, USA, July-August 2011; pp. 135-141. Available online: https: //hbr.org/2011/07/adaptability-the-new-competitive-advantage (accessed on 24 July 2020).

13. Kirchherr, J.; Reike, D.; Hekkert, M. Conceptualizing the circular economy: An analysis of 114 definitions. Resour. Conserv. Recycl. 2017, 127, 221-232. [CrossRef]

14. Jalali, H.; Ansaripoor, A.H.; De Giovanni, P. Closed-loop supply chains with complementary products. Int. J. Prod. Econ. 2020, 229, 107757. [CrossRef]

15. Rajeev, A.; Pati, R.K.; Padhi, S.S.; Govindan, K. Evolution of sustainability in supply chain management: A literature review. J. Clean. Prod. 2017, 162, 299e314. [CrossRef]

16. De Giovanni, P. Dynamic Quality Models and Games in Digital Supply Chains; Springer Nature: Cham, Switzerland, 2020; To appear.

17. Meredith, J. Building operations management theory through case and field research. J. Oper. Manag. 1998, 16, 439-452. [CrossRef]

18. Bressanelli, G.; Perona, M.; Saccani, N. Challenges in supply chain redesign for the Circular Economy: A literature review and a multiple case study. Int. J. Prod. Res. 2019, 57, 7395-7422. [CrossRef]

19. Voon-Hsien, L.; Ooi, K.-B.; Chong, A.Y.-L.; Lin, B. A Structural Analysis of Greening the Supplier, Environmental Performance and Competitive Advantage. Prod. Plan. Control 2015, 26, 116-130.

20. Dan, D.; Dobrotă, G. An Innovative Method in the Regeneration of Waste Rubber and the Sustainable Development. J. Clean. Prod. 2018, 172, 3591-3599.

21. Lacy, P.; Rutqvist, J. Waste to Wealth: The Circular Economy Advantage; Springer: London, UK, 2016.

22. De Giovanni, P.; Ramani, V. Product cannibalization and the effect of a service strategy. J. Oper. Res. Soc. 2018, 69, 340-357. [CrossRef]

23. Hervani, A.; Helms, M.; Sarkis, J. Performance measurement for green supply chain management. Benchmark. Int. J. 2005, 12, 330-353. [CrossRef] 
24. Cui, H.; Song, X. The Study on Countermeasures of Promoting Energy-Saving and Emissions-Reducing Based on Circular Economy Theory. In Proceedings of the 2009 IITA International Conference on Services Science, Management and Engineering, Zhangjiajie, China, 11-12 July 2009; pp. 333-335.

25. Hussain, M.; Malik, M. Organizational enablers for circular economy in the context of sustainable supply chain management. J. Clean. Prod. 2020, 256, 120375. [CrossRef]

26. Dhakal, M.; Smith, M.H.; Newbery, R. Secondary market: A significant aspect in reverse logistics and sustainability. Int. J. Soc. Sustain. Econ Soc. Cult. Con. 2016, 12, 24-35. [CrossRef]

27. Genovese, A.; Acquaye, A.A.; Figueroa, A.; Koh, S.C.L. Sustainable supply chain management and the transition towards a circular Economy: Evidence and some applications. Omega 2017, 66, 344e357. [CrossRef]

28. Genc, T.S.; De Giovanni, P. Optimal return and rebate mechanism in a closed-loop supply chain game. Eur. J. Oper. Res. 2018, 269, 661-681. [CrossRef]

29. Lovins, A.; Braungart, M. A New Dynamic_Effective Business in a Circular Economy, 2nd ed.; Ellen MacArthur Foundation Publishing: Cowes, UK, 2014.

30. Weetman, C. A Circular Economy Handbook for Business and Supply Chains: Repair, Remake, Redesign, Rethink; Kogan Page: New York, NY, USA, 2017.

31. Lombardi, D.R.; Laybourn, P. Redefining industrial symbiosis: Crossing academic-practitioner boundaries. J. Ind. Ecol. 2012, 16, 28-37. [CrossRef]

32. De Giovanni, P. Blockchain and smart contracts in supply chain management: A game theoretic model. Int. J. Prod. Econ. 2020, 228, 107855. [CrossRef]

33. Kouhizadeh, M.; Zhu, Q.; Sarkis, J. Blockchain and the circular economy: Potential tensions and critical reflections from practice. Prod. Plan. Control 2020, 31, 950-966. [CrossRef]

34. De Giovanni, P. Eco-Digital Supply Chains Through Blockchains. SSRN Electron. J. 2019. [CrossRef]

35. Prosman, E.J.; Sacchi, R. New environmental supplier selection criteria for circular supply chains: Lessons from a consequential LCA study on waste recovery. J. Clean. Prod. 2018, 172, 2782-2792. [CrossRef]

36. De Giovanni, P. Smart Supply Chain with Vendor Managed Inventory, Coordination, and Environmental performance. Eur. J. Oper. Res. 2020, 282. in press. [CrossRef]

37. Withers, P.J.; Doody, D.G.; Sylvester-Bradley, R. Achieving sustainable phosphorus use in food systems through circularisation. Sustainability 2018, 10, 1804. [CrossRef]

38. Italian Circular Economy Stakeholder Platform. Strumenti per la Misurazione Dell'economia Circolare. 2018. Available online: https://www.icesp.it/sites/default/files/DocsGdL/REPORT_GdL3\%20Strumenti\%20per\% 201a\%20misurazione\%20dell\%E2\%80\%99economia\%20circolare_0.pdf (accessed on 30 September 2020).

39. EU. Waste Prevention and Management-Environment-European Commission. 2020. Available online: https://ec.europa.eu/environment/green-growth/waste-prevention-and-management/index_en.htm (accessed on 24 July 2020).

40. De Luca, A.I.; Iofrida, N.; Leskinen, P.; Stillitano, T.; Falcone, G.; Strano, A.; Gulisano, G. Life cycle tools combined with multi-criteria and participatory methods for agricultural sustainability: Insights from a systematic and critical review. Sci. Total Environ. 2017, 595, 352e370. [CrossRef]

41. ISO. ISO 14040 International Standard. In Environmental Management_Life Cycle Assessment_Principles and Framework; International Organisation for Standardization: Geneva, Switzerland, 2006.

42. Sala, S.; Beylot, A.; Corrado, S.; Crenna, E.; Sanyé-Mengual, E.; Secchi, M. Indicators and Assessment of the Environmental Impact of EU Consumption. 2020. Available online: https://publications.jrc.ec.europa.eu/ repository/bitstream/JRC114814/science_for_policy_report_final_on_line.pdf (accessed on 24 July 2020).

43. Guinee, J.B.; Heijungs, R.; Huppes, G.; Zamagni, A.; Masoni, P.; Buonamici, R.; Rydberg, T. Life cycle assessment: Past, present, and future. Environ. Sci. Technol. 2011, 45, 90-96. [CrossRef]

44. Finnveden, G.; Hauschild, M.Z.; Ekvall, T.; Guinée, J.; Heijungs, R.; Hellweg, S.; Suh, S. Recent developments in life cycle assessment. J. Environ. Manag. 2009, 91, 1-21. [CrossRef] [PubMed]

45. Leising, E.; Quist, J.; Bocken, N. Circular Economy in the building sector: Three cases and a collaboration tool. J. Clean. Prod. 2018, 176, 976-989. [CrossRef]

46. Domenech, T.; Bleischwitz, R.; Doranova, A.; Panayotopoulos, D.; Roman, L. Mapping Industrial Symbiosis Development in Europe_typologies of networks, characteristics, performance and contribution to the Circular Economy. Resour. Conserv. Recycl. 2019, 141, 76-98. [CrossRef]

47. De Giovanni, P.; Vinzi, V.E. The benefits of the emissions trading mechanism for Italian firms: A multi-group analysis. Int. J. Phys. Distrib. Logist. Manag. 2014, 44, 305-324. [CrossRef] 
48. Mirzaee, H.; Naderi, B.; Pasandideh, S.H.R. A preemptive fuzzy goal programming model for generalized supplier selection and order allocation with incremental discount. Comput. Ind. Eng. 2018, 122, $292 \mathrm{e} 302$. [CrossRef]

49. Caniels, M.C.; Gehrsitz, M.H.; Semeijn, J. Participation of suppliers in greening supply chains: An empirical analysis of German automotive suppliers. J. Purch. Supply Manag. 2013, 19, 134-143. [CrossRef]

50. Cao, M.; Zhang, Q. Supply chain collaboration: Impact on collaborative advantage and firm performance. J. Oper. Manag. 2011, 29, 163-180. [CrossRef]

51. Kopfer, H.; Kotzab, H.; Corsten, D.; Felde, J. Exploring the performance effects of key-supplier collaboration. Int. J. Phys. Distrib. Logist. Manag. 2005, 35, 445-461.

52. Hartmann, J.; Moeller, S. Chain liability in multitier supply chains? Responsibility attributions for unsustainable supplier behavior. J. Oper. Manag. 2014, 32, 281-294. [CrossRef]

53. Konys, A. Green supplier selection criteria: From a literature review to a comprehensive knowledge base. Sustainability 2019, 11, 4208. [CrossRef]

54. De Giovanni, P.; Cariola, A. Process innovation through industry 4.0 technologies, lean practices and green supply chains. Res. Transp. Econ. 2020, 100869. [CrossRef]

55. Taghikhah, F.; Voinov, A.; Shukla, N. Extending the supply chain to address sustainability. J. Clean. Prod. 2019, 229, 652-666. [CrossRef]

56. De Giovanni, P. State-and control-dependent incentives in a closed-loop supply chain with dynamic returns. Dyn. Games Appl. 2016, 6, 20-54. [CrossRef]

57. EIO (Eco-Innovation Observatory). The Eco-Innovation Challenge: Pathways to a Resource-Efficient Europe. Brussels, Belgium: European Commission, Directorate-General for the Environment; EIO: Brussels, Belgium, 2011.

58. OECD (Organization for Economic Co-operation and Development). Eco-Innovation in Industry: Enabling Green Growth; OECD: Paris, France, 2009.

59. Bowen, F.E.; Cousins, P.D.; Lamming, R.C.; Faruk, A.C. Horses for courses: Explaining the gap between the theory and practice of green supply. In Greener Management International Autumn; Greenleaf Publishing: London, UK, 2001; pp. 41-60.

60. Zhang, H.; Yang, F. On the drivers and performance outcomes of green practices adoption. Ind. Manag. Data Syst. 2016, 116, 2011-2034. [CrossRef]

61. Liu, B.; De Giovanni, P. Green process innovation through Industry 4.0 technologies and supply chain coordination. Ann. Oper. Res. 2019, 1-36. [CrossRef]

62. Paquin, R.L.; Busch, T.; Tilleman, S.G. Creating economic and environmental value through industrial symbiosis. Long Range Plan. 2015, 48, 95-107. [CrossRef]

63. Lehr, C.B.; Thun, J.H.; Milling, P.M. From waste to value-A system dynamics model for strategic decisionmaking in closed-loop supply chains. Int. J. Prod. Res. 2013, 51, 4105-4116. [CrossRef]

64. El Hachem, W.; De Giovanni, P. Accelerating the transition to alternative fuel vehicles through a Distributive Justice perspective. Transp. Res. Part D Transp. Environ. 2019, 75, 72-86. [CrossRef]

65. Firnkorn, J.; Müller, M. Selling mobility instead of cars: New business strategies of automakers and the impact on private vehicle holding. Bus. Strategy Environ. 2012, 21, 264-280. [CrossRef]

66. Leandro, A.; Paixao, S. Corporate Social Responsibility and Circular Economy: Two ways, same destinations? An outlook on both concepts and cases from Portugal. In Proceedings of the Congrès avniR, Lille, Portugal, 7 November 2018.

67. Vollero, A.; Conte, F.; Siano, A.; Covucci, C. Corporate social responsibility information and involvement strategies in controversial industries. Corp. Soc. Responsib. Environ. Manag. 2019, 26, 141-151. [CrossRef]

68. Bhattacharya, C.B.; Sen, S. Doing better at doing good: When, why, and how consumers respond to corporate social initiatives. Calif. Manag. Rev. 2004, 47, 9-24. [CrossRef]

69. Du, S.; Battacharya, C.B.; Sen, S. Maximizing business returns to corporate social responsibility (CSR): The role of CSR communication. Int. J. Manag. Rev. 2010, 12, 8-19. [CrossRef]

70. McWilliams, A.; Siegel, D.S.; Wright, P.M. Corporate social responsibility: Strategic implications. J. Manag. Stud. 2006, 43, 1-18. [CrossRef]

71. Muñoz-Torres, M.J.; Fernández-Izquierdo, M.Á.; Rivera-Lirio, J.M.; Ferrero-Ferrero, I.; Escrig-Olmedo, E.; Gisbert-Navarro, J.V.; Marullo, M.C. An Assessment Tool to Integrate Sustainability Principles into the Global Supply Chain. Sustainability 2018, 10, 535. [CrossRef] 
72. European Commission. The EU Environmental Implementation Review 2019 Country Report-ITALY. 2019. Available online: https://ec.europa.eu/environment/eir/pdf/report_it_en.pdf (accessed on 30 September 2020).

73. Kotzab, H.; Seuring, S.; Müller, M.; Reiner, G. (Eds.) Research Methodologies in Supply Chain Management; Springer Science \& Business Media: Berlin, Germany, 2006.

74. Preeker, T.; De Giovanni, P. Coordinating innovation projects with high tech suppliers through contracts. Res. Policy 2018, 47, 1161-1172. [CrossRef]

75. ENEL and Symbola Foundation. 100 Italian Circular Economy Stories. 2018. Available online: http: //www.symbola.net/assets/files/100storie_DEF_Web_pag\%20singole_25-05-18_1527247969.pdf (accessed on 30 September 2020).

Publisher's Note: MDPI stays neutral with regard to jurisdictional claims in published maps and institutional affiliations.

(C) 2020 by the authors. Licensee MDPI, Basel, Switzerland. This article is an open access article distributed under the terms and conditions of the Creative Commons Attribution (CC BY) license (http://creativecommons.org/licenses/by/4.0/). 